\title{
Political legitimacy in Japan: a Luhmannian perspective
}

\author{
Andrew Mitchell
}

Kumamoto University, Japan

\begin{abstract}
Despite widespread public opinion against many of his policies, Abe Shinzo's Liberal Democratic Party (LDP) is not only maintaining its electoral success but expanding on it. Furthermore the LDP has been in almost continual power since 1955, making Japan in the eyes of some a de facto one-party state. This paper will explore the question of legitimacy in Japan's political system, especially the ones raised by Karel van Wolferen the 1980s, and whether the current power structure can be considered to hold it. Through using Niklas Luhmann's social systems theory, in particular his concept of political legitimacy, it will be shown that while electoral reforms in 1994 addressed most of the systemic legitimacy issues in Japan's political system, a potential deficit in the government/opposition coding remains.
\end{abstract}

url:

\section{Introduction.}

Abe Shinzo, the current Prime Minister of Japan and leader of the Liberal Democratic Party (LDP), has proved to be a divisive leader since his return to office in 2012. Opinion polls show clearly that voters are discontent with his proposed constitutional changes, restart of nuclear plants, and childrearing support policies; many feel that his “Abenomics” policies have so far failed to improve Japan's economy ('ASAHI POLL', 2016).

Despite this, the LDP under Abe continues to win election after election. In July 2016, Japan went to the polls to elect half the members of Japan's upper house. It won (with its junior partner Komeito) 70 out of the 121 contested seats, with the main opposition Democratic Party (DP) losing 15 seats ('Diet control', 2016).

The puzzle of LDP dominance despite public disapproval of policies (and the inability of the opposition to mount a coherent strategy to dislodge them) is not a recent phenomenon. Since the inception of the 1955 system, so called as this is when the conservatives and socialist parties coalesced into two main parties and formed the foundation of the modern electoral system, the LDP has been in power almost without break. The only sustained period of opposition control was 200912, after which voter confidence with them collapsed and the LDP was returned to power by a landslide result. Given such a situation it is not hard to see why some have labelled Japan a one party state.

The situation is best described through two anomalies noted in the Japan Times: “A one-party democracy seems an oxymoron. Opposition parties function after a fashion, but fleeting interludes

Corresponding author: Andrew Mitchell; e-mail: andrew.mitchell.leeds@gmail.com 
aside.... the Liberal Democratic Party regime, all but unchallengeable for 6o years, remains so for the foreseeable future" and "It is one thing for peaceful citizens to submit to legislation they disapprove of, if they can't change it. It is quite another for them to support the government responsible, as they consistently tell pollsters they do" (Hoffman, 2016). Given this situation of rule by one party who continually push forward policies which find public opposition, yet do not suffer the expected punishment at the ballot box, how can the Japanese government be seen as legitimate?

This paper will discuss the problem of legitimacy within Japan's political system. I shall first look at the discussion on legitimacy in Japan, exploring the legitimacy issues raised by Karel van Wolferen and how they were entrenched by the ' 55 system. I shall then discuss the 1994 reforms and their failure to spurn a two-party state. I shall then consider this problem through Niklas Luhmann's political sociology, in particular his theory of legitimacy. As Luhmann's theory places legitimacy inside the political system, and not dependent on a system of values or external norms, his theory presents a novel way in which to understand the concept of legitimacy. By applying this to Japanese politics since 1955, I will show how Luhmann's theory can explain the legitimacy of the Japanese system, especially in light of the 1994 electoral reforms and the LDP electoral loss in 2009. It however leaves the question as to what consequences a de facto one-party state may have on the future development of Japanese politics.

\section{The problem of legitimacy in Japan: the enigma of Japanese politics}

Before we can seek to answer a potential legitimacy question we need to carefully define whether there is one and, if so, what form it takes. How to define legitimacy has many schools of thought (Peter, 2016). As Karel van Wolferen noted in his book The Enigma of Japanese Politics, published in 1989, the concept corresponds to a reality that is difficult to measure and seems to only come to the fore when there is a perception of its absence (Wolferen, 1990, p. 357). What is of interest here is when these questions of legitimacy were raised in Japanese society and what the effects of this legitimacy deficit were.

Questions of legitimacy within the Japanese political system first of all need to be limited to the existing reality. Japan seems to be a democratic country: citizens hold all the usual civil liberties and opposition parties contest elections (Scheiner, 2006, p. 1). Yet van Wolferen believed that in 1980s Japan these democratic trappings concealed a rigged one-party system that showed "no demonstrable public influence on important political decisions” (Wolferen, 1990, pp. 42-43). For him the Japanese political system set out to be self-validating as it ignored the requirement for legitimacy to be based on something external, something which transcends the political sphere and can be perceived as ruling the rulers as well as the ruled. Legitimacy can be derived from assuming the person is the primary public value, as it does so in the Constitution of Japan (Beer, 1989, pp. 70-71). For van Wolferen however, the people cannot be truly considered the final arbiter of the power within the Japanese state (Wolferen, 1990, p. 39). A clear problem emerges here with legitimacy: the public are formally the holders of political power but lack the ability to influence the policy of the LDP in a one party system.

Within Western democracies the political order is maintained by what van Wolferen terms an "institutionalised loyal opposition": one which opposes government policy yet is considered legitimate by its position within the political framework (Wolferen, 1990, p. 375). This was not reflected in Japan. Following a Confucian understanding of political order, opposition to rulers is to question their legitimacy: Prime Minister Nakasone, in his election campaign speeches in 1986, echoed the sentiment that only the LDP was capable of ruling responsibly and the opposition was in no fit state to look after the people (Wolferen, 1990, p. 386). The idea of an opposition which it could 
actually lose power to, through the constitutionally sanctioned legitimate authority of the people at the ballot box, was not considered appropriate to the LDP.

The opposition seemed happy to play its role as a symbolic partner in this exercise of power. van Wolferen believed that the opposition wasted its energy on symbolic issues (1990, p. 393) and essentially acted not as a political counter-weight to the LDP but as performers in National Diet ${ }^{1}$ debates who had no influence on the actual developments (1990, p. 45). Deals were cut between LDP and opposition politicians, signs of a normal democracy were present - this though merely hid the underlying legitimacy deficit.

To consider the LDP as a ruling party in the form that one may imagine a Western party is again to blind oneself to the unique structural arrangement of the Japanese political system. Japan operated on "the preservation of a careful balance between semiautonomous groups that share power" (Wolferen, 1986). This is not the same as a government besieged by special interests but marked by rigid but technically informal structural arrangements which mean there was no central authority to go to when a decision is required. One of the main reasons for this was the internal structure of the LDP. The LDP ran along informal factional lines; with each faction having its own power base, own candidates, and own revenue streams. Each faction operated somewhat autonomously within the LDP framework, cutting deals within the party for cash and positions. The ' 55 system could not be considered as the rule of one authoritarian party over another: the LDP itself was highly fragmented and although holding the formal tools for power, internally it had no coherent policy nor any structure that could be identified as a core.

van Wolferen believed that "legitimacy always implies a condition where the right to rule has clearly been established" (Wolferen, 1990, p. 357). The Japanese political system presented itself as a fullyfunctioning democracy to outside observers yet lacked in practice the forms of legitimacy that underpin Western systems. The main issues were an inability for the public to influence policy, an opposition which served only a symbolic function, and a government which operated as a collection of cliques rather than a centralised unit. A government acting under its own initiative for vested interest groups, excluding in various informal ways both the public and the opposition whilst acting without a clear centre of power itself, is clearly not legitimate.

\section{The 1955 system and SNTV}

How the LDP came to rule Japan in a de facto one-party system can be traced back to the incentives present within the so-called 1955 system. In 1955 the conservatives and socialists coalesced into two main parties: the LDP and the Japan Socialist Party (JSP). This system survived until 1993 and reached the zenith of its rationale by the late 8 os when van Wolferen was writing. There were four pillars holding up the ' 55 system: public support for policies which would enable Japan to achieve its catch up to the West goal, key interest groups integrated with political parties, an immensely powerful bureaucracy, and a one-party system ${ }^{2}$ (Curtis, 1999, p. 39). This section shall discuss two of these elements, the one-party system and the groups integrated within it.

As discussed previously, Japan operated as a one-party headed by a LDP government which had no clearly identifiable centre of power. This arose due to the incentives created by the electoral system. As Rosenbluth and Thies (2010, p. 53) note, "The factions that bedevilled LDP politics from the day the party formed are testament to the powerful centrifugal forces of the Single Nontransferable Vote (SNTV) electoral system".

The effects of the SNTV system can be summarised as follows. Each voter in an electoral district had one vote and voted for a candidate within the district. Multiple members of a party could run in each district as each district sent 2-5 members to parliament. This led to a situation where members not 
only competed against other parties but also candidates from their own party. Policy differences thus become less important than personalism. Candidates appealed to a section of the electorate in their district, promising jobs and pork barrel spending in return for votes. The only way this could be funded was by factions within the LDP funding their candidates to run against the candidates of opposing factions. Policy and national level politics became moot in the face of personalism being the most effective way to gain votes.

The reason the LDP managed to stay in power for thirty eight years until 1993 was because its electoral machine was the most capable of channelling funds to its voters. The LDP at formation was a mixture of conservative parties; the SNTV system ensured that these parties, now factions, would continue to compete against each other. Such intra-party competition required huge pools of funds. To have the money to do this, the LDP created what has been called the steel and rice coalition. The LDP relied on large donations from modern sectors of the economy (the steel) in order to finance the uncompetitive sectors which contained the LDP's core voters (especially farmers, hence rice) (Rosenbluth \& Thies, 2010, p. 54). The LDP integrated various interests groups into its electoral machine which would then be rewarded as needed. Through using other government levers of control such as tax breaks, the LDP managed to keep this coalition going until the internal tensions between productive and non-productive sectors, combined with the bursting of the bubble economy, led to the collapse of the SNTV system in 1993 (Rosenbluth \& Thies, 2010, p. 69).

Whilst the LDP was winning elections fairly, it was doing so under conditions where it would be extremely difficult for the opposition to compete financially in order to overcome the biases present with the SNTV system. The opposition also could not form a coherent strategy to dislodge the LDP in these circumstances and, as van Wolferen notes, performed little more than a symbolic role. The LDP essentially hijacked the electoral system and operated it in order to reward its interest groups rather than create policy which would serve the population at large. It is difficult to see how the manifest corrupt present in a system which favoured personalism and patronage over substantial policy can be seen as legitimate.

\section{The electoral reforms of 1994 and their results on the LDP}

The breaking point occurred in 1993 when a bitter struggle broke out within the largest LDP faction. This triggered a sequence of events which led to the secession of many LDP politicians into a newly formed rival party and the collapse of the LDP government (Curtis, 1999, p. 65). What emerged in August 1993 was a coalition of seven parties, which itself collapsed eight months later (Curtis, 1999, p. 99). This coalition had only one unifying goal: that of electoral reform. Once this goal was completed, the intractable divisions between the constitute groups allowed the LDP to regain power (albeit in a coalition of its own with a JSP Prime Minister).

The rebellion was led by Ozawa Ichiro, an LDP politician who was influenced by Karel van Wolferen and believed that Japan needed a two-party system which would force parties to adopt clear policy positions (and therefore break the link between pork and votes) (Murphy, 2014, pp. 294-295). His aim in creating this was to strengthen the legitimacy of the political system as well as strengthen the authority of the national political leaders (Mulgan, 2014, p. 25). Ozawa's position can be considered as emerging from the realisation of the problems inherent in the ' 55 system, and the understanding that these need to be changed radically in order for the Japanese political system to be considered legitimate. To this end, Ozawa helped to push through the 1994 electoral reforms.

What emerged from the electoral reforms was the replacement of the SNTV system with a mixed member majoritarian (MMM) system. Under this system voting is mixed. Voters now have two votes: one for a candidate standing for election in a district, and one for a party whose final vote share will 
be determined nationally under proportional representation (PR). This erased and created various incentives within the Japanese voting system. Gone were the multimember districts of old. Candidates from the same party no longer could compete with each other for votes: they competed only against rival parties. The PR aspect helped to alleviate the potential bias of this system towards big parties by granting smaller parties who gather enough national votes a number of seats in the National Diet's lower house. The design of this system aimed to erase the incentives towards money and personalism and reintroduce policy as a defining factor in elections.

The semiautonomous coalition of cliques that was the LDP under the ' 55 system led to the organisation being popularly described as being neither liberal, nor democratic, nor a party (Murphy, 2014, p. 113). Ozawa's reforms first of all needed to break the faction system within the LDP which led to the lack of political centre. Factions in the form they took under SNTV seem to have not survived the transition to MMM (Rosenbluth \& Thies, 2010, p. 108). Factions are now more akin to groups within political parties the world over rather than semi-permanent organisations which informally contest control of the larger party.

The dwindling power of factionalism was illustrated by the election of Koizumi Junichiro as the president of the LDP (and thereby the Prime Minister of Japan) in 2001. Koizumi was considered an outsider within the party's traditional factional system. A newly introduced primary system however, modelled on American lines, allowed the party members their say in the LDP leadership contest and they overwhelmingly backed Koizumi (Murphy, 2014, p. 303). Whilst this result was non-binding, the party's National Diet members could not ignore the result. Koizumi then struggled against his own party for post-office privatisation on the national stage ${ }^{3}$. When his postal privatization bill failed in the National Diet, Koizumi called a snap election and made it a mandate on his proposed reforms. He won by a landslide and those against his plans were deemed "postal rebels" and expelled from the party (Murphy, 2014, p. 310). Koizumi's actions were the first clear examples of the waning power of LDP factionalism and the rise of centralised, popular, leadership.

The atrophying power of factions has reached the point where Abe Shinzo is relying more and more on the support of voters (Yoshida, 2016), finding a political mandate through the polls rather than power derived from factional support. The decline in factionalism and the subsequent rise in centralised leadership seems to have solved the underlying problem of "power without a centre" that van Wolferen identified.

The changes present within the 1994 system have also led to a rise of coalition government. The emergence of a de-facto LDP-Komeito coalition government since 2003 has meant the LDP have not held sole rule since the 1994 electoral reforms (Rosenbluth \& Thies, 2010, p. 105). Komeito attracts an urban vote of shopkeepers and small businesses, a much different voting block than the LDP has traditionally attracted. (Murphy, 2014, pp. 122-123). It provides a voice for these marginalised groups within the political system (Murphy, 2014, p. 275), one that had traditionally been ignored it under the steel and rice coalition. Perhaps most importantly, its inclusion within government means that the LDP is forced to act more as a unified party within a coalition rather than an aggregate of interests which exist under the pretence of a political party.

The voting reforms have changed the LDP in ways which have solved many of the legitimacy problems van Wolferen identified. Factionalism is but a shadow of its former self, Abe Shinzo is continuing the trend of justifying his policies on an electoral mandate, and the Komeito coalition introduced the voices of urban voters into government. The LDP may not be liberal or democratic, but it at least now resembles a political party.

\section{The continuing problem of political opposition in Japan}


The electoral reforms had a wide effect on the LDP but did the changes created the conditions for the emergence of a genuine two-party system? As discussed in the introduction, Japan has not emerged as a two-party state and the continuing victories of the LDP have raised questions as to whether this state of affairs can be considered legitimate.

Gerard Curtis as early as 1999 foresaw that it was far from clear as to whether Japanese politics would evolve towards a two-party system. Curtis believed that only the emergence of a deeply polarizing division within Japanese society would be enough to spur Japan's middles classes into antagonistic groupings (using hypotheticals such as mass layoffs or a collapse in the US-Japan security alliance as examples) (Curtis, 1999, pp. 166-167). A geopolitical explanation by Stratfor agrees with this point, believing that Japan has not broken from the status quo since the end of the Cold War due to the country's economic and demographic problems appearing relatively mild to the ordinary Japanese person ('Forecasting Japan', 2015a). The same analysis locates the point of radical change as most likely to emerge not internally but by a transforming China, forcing Japan to question its national interests ('Forecasting Japan', 2015b) and serving as the polarising event Curtis envisages.

The opposition did manage to gain power though in the 2009 election, by a landslide. This was the first time the LDP had lost power since 1955 through the actions of the opposition rather than through the defection of politicians from its own ranks. First it should be noted how the opposition came to find itself electable. Japan, after the departure of Koizumi from the Prime Minister's Office in 2006, found itself cycling through prime ministers on a yearly basis. Ozawa during this time built up his Democratic Party of Japan (DPJ) into true electoral contenders (Murphy, 2014, p. 312). The 2008 financial crash was the final nail in the coffin for the LDP and in 2009 the DPJ finally took office. The reason for this was in large part due to the new electoral system allowing Japanese voters to more easily express their frustration with the LDP at the ballot box, with polls showing voters had higher expectations of the DPJ than the LDP (Shinoda, 2013, p. 150). Ozawa's wish for a two-party system seemed to have been realised.

Yet only three years later the DPJ were voted out by a landslide and have faced crushing defeats since. This was in no small part due to it being blamed for perceived economic mismanagement and the near catastrophe at Fukushima (Murphy, 2014, p. 355). This led to a collapse in voter confidence in the DPJ which lingers to this day. The DPJ, now reformed as the Democratic Party (DP), have consistently failed to construct a new policy base or compete against the LDP in any meaningful way since its loss. Despite the promising signs for the emergence of a genuine two-party state, Japan seems to have reverted to the one-party model once again.

Oguma Eiji in a recent paper asks the question of how the LDP is winning elections. He suggests that the LDP and Komeito have a superior organised vote, meaning that if overall turnout is less than $60 \%$ the LDP/Komeito candidate will usually win (Oguma, 2016, p. 19). Furthermore it was not the electoral appeal of the LDP which allowed it to be elected: it has consistently lost votes since its 2009 electoral loss. It is the loss of voter confidence in the DPJ and the abstention of many voters, combined with the LDP 'riding the coattails of the DPJ's mistakes', which has given it electoral victories since 2012 (Oguma, 2016, p. 20).

Oguma also notes two aspects of voter behaviour that lead to LDP victory. The first is that there is not a particularly strong relation between the party one votes for and one's views on issues the DPJ have picked up, such as nuclear power (Oguma, 2016, p. 21). More important is the 'traditional village' politics which still dictate Japanese political life in the 21st century. Quoting a former LDP National Diet member, as well as referring to Curtis' work on elections in Oita prefecture in the 196os, Oguma believes that local communities care little for national politics and vote for politicians based on their involvement in the local community, not on any national policies the politician may 
have helped enact or any wider political views they hold (Oguma, 2016, p. 22). Oguma states that Koizumi tried to move away from this system and the LDP was eventually punished by losing government. On its return to power, it again sought to prioritise this source of votes in order to maintain electoral success (Oguma, 2016, p. 23).

This view would coincide with Curtis and Stratfor's analysis that only a divisive issue would drive people to vote on national policy and form a two-party system. Voters found cause to remove the LDP in the wake of the 2008 financial crash but this was also due to the opposition presenting itself as electorally credible and showcasing clear policy positions, thus presenting a clear alternative to LDP rule. The DP currently presents no such alternative to Abenomics and the LDP's policy positions. Yet there are clear dividing lines within politics. Protest groups like SEALDs ${ }^{4}$ have emerged which claim the LDP, by passing new security bills, are denying the fundamental principles of the constitution ('Sealds Eng', 2016). There are divisive issues in Japan yet the main opposition is unable to pick up on this and make them a vote-winner.

The 1994 reforms therefore have so far failed to spur the full evolution of political legitimacy that van Wolferen identified as lacking and Ozawa believed would result from electoral reform. Japan is still effectively a one-party state and whilst thinkers like Curtis and Oguma have proposed structural factors which are preventing a two-party state from fully emerging, it does not solve the legitimacy problem identified.

\section{Luhmann's theory of political legitimacy}

So far this paper has demonstrated some of the issues with political legitimacy in Japan. What if these perceived deficits are due to a misunderstanding of the concept of legitimacy rather than a problem of legitimacy itself? The sociological works of Niklas Luhmann present an alternative framework for us to understand legitimacy which reframes the issue of it within Japan.

Luhmann's political sociology is predicated on the political system "supplying the capacity to enforce collectively binding decisions", decisions which both bound the decision maker as well as the addressee to the decision ${ }^{5}$ (Luhmann, 1990a, pp. 73-74). This rather narrow definition of political functioning denies the typical political science position that politics forms a dominant resource and thus takes a dominant position in society. In other words, politics no longer serves as the focal point for what a society is, it merely acts in order to regulate it through a decision-making process which is distilled through law and predicated on its monopoly on physical coercion.

Chris Thornhill picks up on the wider implications of this. This denial of political importance means that politics does not form a "dominant horizon for all areas of human life": such assumptions are, for Luhmann, residues of previous self-descriptions of the political system which relied on concepts such as sovereignty (Thornhill, 2006, p. 35). Sovereignty relies on a distinction between ruler and ruled. The replacement of this distinction for one between state and society allowed one to begin to recognise the functional differentiation between an economic order of society and the constitutional interests of the state (Luhmann, 1990a, p. 133).

The standard concepts of political theory rest on, in Luhmann's opinion, normative accounts which believe that truth/consensus can deduced, turned into obligatory principles, and then be used to hold the political system to account (Thornhill, 2006, p. 36). This highly simplified model of rationality ignores the fact that different social systems produce different forms of rationality which are irreducible to each other: it is systemic differentiation, not structural convergence, which is the hallmark of modernity. The Enlightenment principles of political theory therefore suffer from a "sociological deficit" by blinding itself to the highly contingent and complex way in which society 
conducts its communications (Thornhill, 2006, pp. 36-37). Normative foundations have for Luhmann lost their power (Luhmann, 1990a, p. 152).

Luhmann's description of political legitimacy loses any grand vision of truth and values and operates on pure contingency, with operations being legitimised through the system itself rather than reference to an external point. As Luhmann noted in the early 9os, there are over five billion "psychological systems" and it is unreasonable to expect these to provide anything more than "individual-psychological knowledge" (Luhmann, 199ob, p. 78). Luhmann's theory then replaces the anthropocentric core of traditional theories of legitimacy with one reliant on system operation.

Yet the problem of the political system is that it requires legitimacy: the political system can only make sense of its communications "under the condition of legitimacy" (King \& Thornhill, 2003, p. 72) In regards to legitimacy, the Enlightenment account lazily assumes that the human subject is the source and explanation of truth and legitimacy, leading to the false question of under what conditions political domination is acceptable. Only a self-referential concept of legitimacy can overcome this anthropocentric understanding of legitimacy and refocus it on, as Luhmann put it, "whether and under what conditions a differentiated political system, specified on the production of binding decisions, can be stabilized in its societal environment"(as cited in Thornhill, 2006, p. 38).

Grounds for a revaluation of the problem of legitimacy in Japan already present themselves. van Wolferen's claims that legitimacy must arise from something outside the political system is for Luhmann a remnant of a metaphysical position which ignores the sociological consequences of modernity. The constitutional state may be the hallmark of modernity but this is not due to the realisation of Enlightenment principals: it is due to the functional differentiation of modern society. The concept of the people being the underlying legitimacy of the constitutional state is undermined by Luhmann as the very concept lazily refers to the abstract concept of a people, as if one can draw from this fiction legitimate rules for the use of power. In this regard, Luhmann's theory reopens the question of legitimacy by making it a question to be solved sociologically by operations taking place within society, not through norms which supposedly transcend the systems they are meant to underpin. As legitimacy becomes a system-internal referent, the ability for one to claim illegitimacy based on values or rights disappears.

Japan evidently meets the criteria for legitimacy that Luhmann has used here to construct his theory. Japan's political system is extremely stable and the collectively binding decisions it passes into law are obeyed. Even highly controversial policy positions such as restarts of nuclear plants and constitutional reinterpretations find no dissent outside of peaceful, law-abiding, protest. At a very basic systemic level the Japanese political system is legitimate as it succeeds in its narrow focus of binding society to its decisions.

\section{A systems theory of Japanese political opposition}

This concept of legitimacy leaves us with a problem: political power cannot just be legitimate because it is legitimate. This says nothing about why those in power have the legitimacy to rule and nothing about how one can conceive of challenging this rule. Luhmann solves the problem of sovereignty taking the form government/governed (as it exists within the constitutional state) by introducing the secondary coding of government/opposition in order to create legitimation (Luhmann, 1990a, p. 170). The government retain domination over the governed but now we have an organised opposition within the political system which can compete for power based on the prevailing rules within a particular political system.

The justification of a multi-party system is found, in Luhmann's opinion, in the necessity of having political options: certainty about the future cannot be known in advance so it "makes sense to talk 
about alternatives.... to oppose them to one another" (Luhmann, 1990a, p. 100). Opposition exists then not only for the sake of contingency in government but to introduce "new themes into political communication"(King \& Thornhill, 2003, p. 121). The opposition can test new themes for electoral resonance which it can then raise within the political system. These alternatives both provide the government/opposition as well as the public with contingency as the political system has options in how it acts.

This requires a further way for one to choose between the government and opposition: this is done by reference to the "excluded third-value": the public. It is at this juncture the political system allows those subject to domination the chance to dominate itself (though only ever through the regulated rules of voting). For Luhmann this "reflexivity of power relations" allows the "inclusion of the audience in the differing-out of the political system" (cited by Moeller, 2011, p. 94).

Luhmann's theory succeeds here as it allows, as Moeller describes it, a "stability by flexibility": we have stability from allowing a certain amount of instability within the system (Moeller, 2011, p. 91). The coding government/opposition works with the positive value of government (which has the legitimate power to enact and enforce decisions) while the opposition acts as the contingency within the political system that things could have been different.

For Luhmann democracy is not the high point of virtue or humanism: it is merely the "structural innovation emerging.... as a result of mere historical chance", i.e. the emergence of modern differentiated society (Luhmann, 1990a, p. 234). Through viewing politics through social systems theory, Luhmann shows that "the differentiation of special functional systems gives rise to related contingency formulae that can assert system-specific indisputability, for instance... legitimacy for the political system"(Luhmann, 2012, p. 282). Legitimacy is created through the contingent operations of the secondary coding of government/opposition which allows things to change in an ordered way and the public to take part in this contingent process.

Unlike other theories of legitimacy however Luhmann considers the "twin ideas of participation and legitimation" a disaster and that the term legitimation should solely be concerned with the predictive and "practico-rhetorical problems of re-electing or not re-electing governments - no more, no less" (Luhmann, 1990a, p. 222). For Luhmann then, what is important is the fact the political system can manage its own contingency rather than the idea that participation directly makes a government legitimate.

In the Japanese case, since 1955 there has been an opposition which has provided the other side of the government/opposition distinction, with regular elections allowing the public to choose between them. As clearly illustrated earlier in this paper however, the SNTV system led to the election system being ran for interest groups linked to the LDP rather than for the public at large. On one hand, this was not a problem as participation for Luhmann is not twinned with legitimation. On the other hand however the lack of an effective opposition led to a government which did not see the public as a means for steering policy direction: without an effective opposition producing new political themes, the LDP was unable to observe its own political environment effectively and this led to the eventual collapse of the ' 55 system. The lack of political opposition led to a lack of political options. The 1994 reforms aimed to solve the problem by making the incentives under the electoral system more about policy than money, helping to reinsert this element of contingency back into the political system.

The government/opposition coding can also be applied internally to the LDP. As Luhmann notes, "system/environment differences can be differentiated within systems" (Luhmann, 1995, p. 18). In other words, the LDP began not to see itself merely as a group of factions but slowly started to form its own internal government/opposition distinction. Going back to Koizumi's postal reforms, it is 
clear that Koizumi saw himself as the government within the LDP again an unruly opposition. Such a move, to call an election in order to gain a mandate and then to expel the rebels from the party, could not have been envisaged under the ' 55 system. This illustrates how the LDP internally has begun to coalesce under the distinction government/opposition and thus resemble a more standard Western party.

As discussed earlier, within the realm of national politics the LDP lost voter confidence as the DPJ built itself a formidable electoral machine, winning power in 2009. Yet since 2012 it has failed to identify with voters and is losing seats. The problem of Japanese society lacking a divisive issue to propel the formation of a two-party state is touched up by Luhmann. He identifies this problem of policy formation in the modern era, when ideological differences have become much less relevant. Governing becomes a choice of making decisions which keep the opposition out of power and parties struggle to differentiate themselves from each other using remnants of the old differences (Luhmann, 1990a, p. 177). This problem becomes acute in the Japanese case, where the LDP have such a traditional source of votes, that it makes it difficult for the opposition to differentiate itself to the degree that it can persuade the floating voters to turn out to elect it. The opposition cannot find a theme in modern Japanese political life which it can use to differentiate itself from the LDP and thus serve as a viable alternative to it.

Using Luhmann's theory, one would have to conclude that there is no legitimacy issue within the Japanese political system. The opposition can and has won power, and the system set-up is so that it can do so again. The public, whilst not being the legitimising factor of politics in this theory, serve to allow the contingent nature of political power to operate legitimately through voting. The emergence of new electoral incentives under the 1994 system seems to have led to the LDP internalising the government/opposition coding and start to resemble a more standard party. Even the current lack of electable opposition cannot be said to question the legitimacy of Luhmann's coding; it seems to be, at least partly, a side-effect of the general problems political parties are facing in creating differences between each other in a post-ideological age.

This lack of opposition however does not bode well for efficient political system functioning. A lack of opposition means a lack of options. Luhmann's primary distinction in his theory, that between system and environment, should be mentioned here as this is perhaps the biggest issue with the state of politics in Japan. For Luhmann one must "distinguish between the environment of a system and systems in the environment of this system" (Luhmann, 1995, p. 17). Under the ' 55 system the LDP ignored both the opposition and the wider social environment the political system operated in. It worked with its interest groups and the bureaucracy in order to create the Japan it believed it needed to. There was no alternative available. In current Japan, without an effective opposition able to introduce new themes into political communication, the LDP runs the risk of not paying enough attention to the wider environment the political system operates in. Simply put, there are no alternative options for it to follow or to spur it into thinking differently. This may not provoke a legitimacy crisis, in fact it would be very unlikely to given the political system's evident robustness. It may however lead to the same inefficiencies being introduced into decision-making that occurred under the ' 55 system and thus exposing Japan to problems that could otherwise have been avoided.

\section{Conclusion}

Japan's legitimacy problem can be traced back to the ' 55 system and the incentives it contained, leading to centrifugal forces keeping the LDP divided internally and the electoral system running on pork instead of policy. Changes in the 1994 reforms led to this problem disappearing but the inability for a coherent opposition to form leaves the perception of a potential legitimacy gap in Japan. 
Luhmann's theory addresses the problem of legitimacy in a different manner, identifying system operations as the key to legitimacy. Despite this theoretical difference, Luhmann's theory can be seen to follow the general political position of the problem of legitimacy in Japan by identifying the organisation of the LDP before 1994, as well as the problem of a political system legitimising itself when it can offer no plausible alternatives. The difference between the classical approach and the Luhmannian one however is that for the second approach the Japanese system has shown itself able to deal with its legitimacy issues by producing new rules and reforms which aid system operation. The fact the opposition under the new system produced an electable government signifies the success of the political system in managing itself and producing legitimacy by "stability through flexibility". That the opposition has yet to reform itself into a viable electoral contender is not a question of legitimacy then - legitimacy exists as the opposition has the ability to do this and the voting public are aware of this contingency, that things could well be different. The Japanese political system has reacted and evolved in the face of previous systemic deficits through the 1994 reforms; it now shows positive signs that the system is able to self-legitimise and continue its primary purpose of creating collectively binding decisions.

This does not necessarily mean however that Japan could not find itself, given the lack of new themes in political communication, suddenly facing a crisis it was blind to by lack of this input. Japan's political system may be able to legitimise itself but without effective opposition it runs the risk of being exposed to environmental changes which it has not had the opportunity to previously consider through the opposition introducing new themes into political communication. This does not necessarily pose a systemic crisis; the potential risks to the livelihoods and wellbeing of the average Japanese person can be debated however. Japan's political system may be able to selflegitimise but its current state leaves it open to potentially disastrous effects it is blind to through a lack of contingency.

Within the context of Luhmann's theory, there are a few strands that have not been explored which could serve as a way to further this discussion. Further points can be raised concerning Luhmann's theory on the cycling of power within the political system; the concept of public opinion and the mass media; protest movements and their meaning for the political system; structural coupling between politics and the economy; and the role of bureaucracy within the modern state. The final two in particular, given the two of the four pillars of the ' 55 system not explored in this paper (the economic catch-up with the West goal and the powerful bureaucracy), may be able to shed further light on the operations of a Japanese government that stubbornly remains without a competent opposition to ensure efficient system operation.

\section{References}

ASAHI POLL: 49\% of voters oppose Abe's drive to rewrite Constitution : The Asahi Shimbun. (2016, March 15). Retrieved 25 September 2016, from http://www.asahi.com/ajw/articles/AJ201603150023.html

Beer, L. (1989). Freedom of expression in Japan. In T. Ishida \& E. S. Krauss (Eds.), Democracy in Japan (pp. 64-87). Pittsburgh, Pa: University of Pittsburgh Press.

Curtis, G. L. (1999). The logic of Japanese politics: leaders, institutions, and the limits of change. New York: Columbia University Press.

Diet control. (2016, July 11). The Economist. Retrieved from http://www.economist.com/news/asia/21701960-upper-house-election-japan-goes-emphaticallyfavour-shinzo-abe-diet-control 
Forecasting Japan: A Slow-Burning Crisis. (2015a, September 28). Retrieved 26 September 2016, from https://www.stratfor.com/analysis/forecasting-japan-slow-burning-crisis

Forecasting Japan: China Rises. (2015b, September 29). Retrieved 26 September 2016, from https://www.stratfor.com/sample/analysis/forecasting-japan-china-rises

Hoffman, M. (2016, March 26). 'Teflon Abe' gets high marks despite unpopular policies. The Japan Times Online. Retrieved from http://www.japantimes.co.jp/news/2016/03/26/national/medianational/teflon-abe-gets-high-marks-despite-unpopular-policies/

King, M., \& Thornhill, C. J. (2003). Niklas Luhmann's theory of politics and law. Basingstoke, Hampshire; New York: Palgrave Macmillan. Retrieved from http://site.ebrary.com/id/10254126

Luhmann, N. (1990a). Political theory in the welfare state. Berlin; New York: W. de Gruyter.

Luhmann, N. (1990b). The Cognitive Program of Constructivism and a Reality that Remains Unknown. In W. Krohn, G. Küppers, \& H. Nowotny (Eds.), Selforganization (pp. 64-85). Springer Netherlands. Retrieved from http://link.springer.com/chapter/10.1007/978-94-017-2975-8_5

Luhmann, N. (1995). Social systems. Stanford, Calif.: Stanford University Press.

Luhmann, N. (2012). Theory of society. Stanford, California: Stanford University Press.

McCurry, J. (2015, September 16). New generation of Japanese anti-war protesters challenge Abe. The Guardian. Retrieved from http://www.theguardian.com/world/2015/sep/16/japanese-anti-warprotesters-challenge-shinzo-abe

Moeller, H.-G. (2011). The Radical Luhmann. Columbia University Press.

Mulgan, A. G. (2014). Ozawa Ichirō and Japanese politics: old versus new. Abingdon, Oxon ; New York, NY: Routledge.

Murphy, R. T. (2014). Japan and the shackles of the past. Oxford ; New York: Oxford University Press.

Oguma, E. (2016). A New Wave Against the Rock: New social movements in Japan since the Fukushima nuclear meltdown | The Asia-Pacific Journal: Japan Focus. The Asia-Pacific Journal: Japan Focus, 14(13). Retrieved from http://apjjf.org/2016/13/Oguma.html

Peter, F. (2016). Political Legitimacy. In E. N. Zalta (Ed.), The Stanford Encyclopedia of Philosophy (Summer 2016). Retrieved from http://plato.stanford.edu/archives/sum2016/entries/legitimacy/

Rosenbluth, F. M., \& Thies, M. F. (2010). Japan transformed: political change and economic restructuring. Princeton: Princeton University Press.

Scheiner, E. (2006). Democracy without competition in Japan: opposition failure in a one-party dominant state. Cambridge ; New York: Cambridge University Press.

Sealds Eng. (2016). Retrieved 23 January 2016, from http://sealdseng.strikingly.com/

Shinoda, T. (2013). Contemporary Japanese politics: institutional changes and power shifts. New York: Columbia University Press.

Thornhill, C. (2006). A Sociological Transformation of Political Legitimacy? Distinktion: Journal of Social Theory, 7(2), 33-53. https://doi.org/10.1080/1600910X.2006.9672928

Wolferen, K. van. (1986, Winter /87). The Japan Problem. Foreign Affairs, (Winter 1986/87). Retrieved from http://www.foreignaffairs.com/articles/41699/karel-van-wolferen/the-japan-problem 
Wolferen, K. van. (1990). The enigma of Japanese power: people and politics in a stateless nation (1st Vintage Books ed). New York: Vintage Books.

Yoshida, R. (2016, August 3). With Cabinet shake-up, Abe lays groundwork for future of LDP. The Japan Times Online. Retrieved from http://www.japantimes.co.jp/news/2016/08/03/national/politicsdiplomacy/cabinet-shake-abe-lays-groundwork-future-ldp/

\footnotetext{
${ }^{1}$ Japan's bicameral legislature. Composed of a lower and upper house, of which the lower is the more powerful.

${ }^{2}$ The catch-up goal was the desire to bring Japanese per-capita incomes and living standards to those seen in the advanced industrialised world (Funabashi \& Kushner, 2015, p. 176). A strong bureaucracy was seen as a vital element in ensuring this could be achieved.

${ }^{3}$ The post office was targeted as "the postal system sat atop trillions of yen in savings deposits, which it passed along to government financial institutions for use in "industrial policy" (Rosenbluth \& Thies, 2010, p. 139). Koizumi recognised that if Japan was going to move forward from politicians using pools of savings in order to entice voters with construction projects in their area, such spigots of cash would need to be removed from government control.

${ }^{4}$ Students Emergency Action for Liberal Democracy, a student activist group which epitomised the protest movement in Japan in 2015 and found exposure in Western media (see McCurry, 2015).

${ }^{5}$ This follows Weber's belief that this is the only focal point possible for the sustained control on the monopoly on physical violence.
} 